Articles 



\author{
Juhan Maiste
}

\title{
THIS CITY AND ANOTHER
}

"This City and Another" is the topic of the autumn school that took place under the roof of the alma mater in autumn 2012. The organisers of the event, the chairs of art history at the University of Tartu and Tallinn University of Technology, brought together the people and the ideas to which the present collection contains a retrospective, offering insight into a topic that has received a great deal of contemporary discussion: urban space. The collection unites articles from people of several backgrounds and different world-views, who offer new perspectives on the three topics of the autumn school: "autumn", "the city" and "the other".

Besides the visible and the tangible, an invisible and non-physical aspect exists in the genius loci ${ }^{1}$ - the spirit of the mind. Postmodern urban theories and the philosophy of heritage protection open a new path to solve issues surrounding the unity of material substance and the human mind. To better understand the "city", analytical and phenomenological approaches must be combined ${ }^{2}$, and clear and distinctive methods of science have to be considered alongside the illusionary and often uncertain sensations we meet in art: we have to conceptualise the city in the entirety of its past and present; our imaginations must bridge the gap between the scientific approach and poetry, opening "inner windows" into the subconscious and to the myriad of fantasies that otherwise re-

\footnotetext{
DOI: http://dx.doi.org/10.12697/BJAH.2013.5.02

Translation by Margus Tuvikene

1 Genius loci is often used in Latin poetry by Horace, Vergil and others. In the theory of architecture, this notion was used first by Christian Norberg-Schultz. See Norberg-Schultz, Genius Loci, Towards a Phenomenology of Architecture (New York: Rizzoli, 1979).

2 In connection with the theories of city planning, see Jussi Jauhiainen, Linnageograafia: linnad ja linnauurimus modernismist postmodernismini (Tallinn: Eesti Kunstiakadeemia, 2006).
} 
main on the fringe. The sanctioned, official memory meets another kind: a deeply personal recollection that lacks authority and warrant, yet is a vivid memory of our experiences in acts of love and hatred. To remember also means to forget. When thinking honestly about the events that have moved and touched us, these moments rarely contain columns of utopian construction, but do contain, besides the intellectual mind, the world of the single person and "simple man".

The editors of this collection are interested in the limitless entirety of the city as it appears in our field of visual perception; the city, which from the beginning of time has served as the practical guide for humans by limning the infinite, bringing people together around the sanctuary and the agora, building communities and communes, forming order out of chaos, paving the roads that, like the arrow-straight Via Appia, have connected hippodromes with harbours; the city, which has established aqueducts and amphitheatres, but has also left room for the unconquered and indefinable Other invisible on the main roads: somewhere in Supilinn or the Reggio di Calabria, where a dutiful mother has hung the laundry to dry.

This text is dedicated to the issue of the cognised and visible space that we adapt to and share with others in space and time, and the opposing force: chaos. The world as we know it involves both geometry and the arts; they constitute an entity that seems to us both natural and graspable in appearance. One might try to form simple proofs, such as (1.) the world is round; (2.) I am walking on a flat and solid surface; (3.) the surface is calm and dry enough to grow apple trees and children. Do these proofs suffice? Yes and no. At the instant we recognise the first and infinite, we also notice the second - the world of an undefined apeiron of the space which we inhabit like ants, or frogs in the swamp: us around our sea. ${ }^{3}$

Myths, hung on the wind, recall times that gave birth to the stars and form to facts, constructing one civilisation on top of another, shift after shift, from the privacy of motion to the primacy of fixity, from experience to the primacy of knowledge Plato called the episteme. ${ }^{4}$ Daedalus framed the thought and coded civilisation, becoming an affirmation of our powers of abstraction: for it can sum up and subtract apple trees

3 Plato, Phaedrus, 109b.

4 Indra Kagis McEwen, Socrates' Ancestor. An Essay on Architectural Beginnings (Cambridge, Mass. \& London: MIT Press, 1993), 6. 


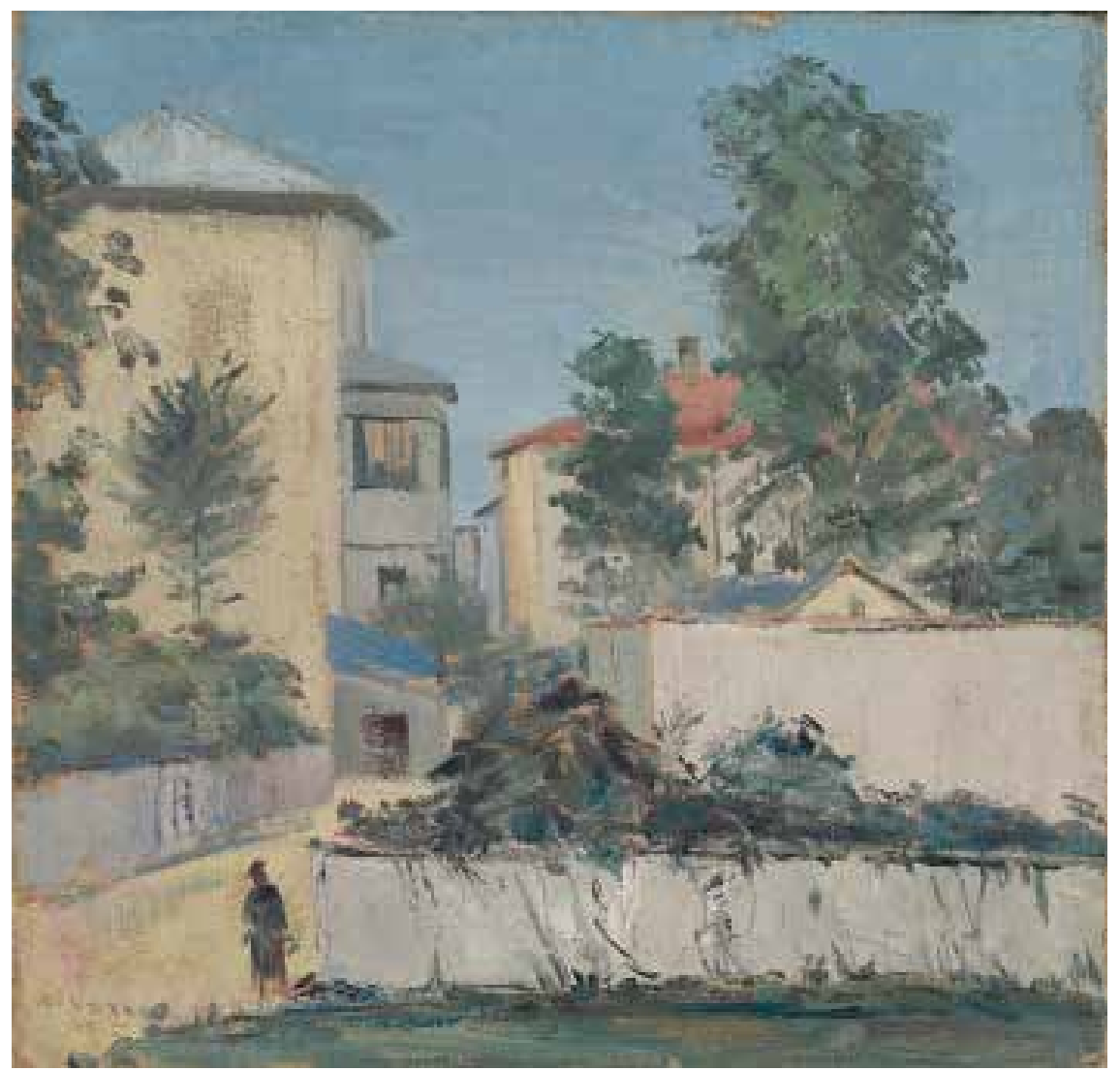

Fig. 1. Ado Vabbe, A View of Tartu from Tähtvere, 1945, Tartu Art Museum

and bird nests alike: the reign of architecture over the living had been established. Vitruvius' firmitas, utilitas and venustas bent both architecture and city planning under the laws of Pythagorean mathematics and Euclidean geometry, making his rules mandatory for all head carpenters (architecton) of the world, establishing the dictate of Classics that promises the gathering of flesh and blood at school every autumn, like rye on the crossbar or wet clothes on the line, allowing history to speak not in the language of memory, but of reminding. The Latin moneo means "to remind" and also "to warn". The moneo that is left out of the loop is an unknown and indefinable area, a cosmos not yet formed, which in its infirmity and frightfulness causes the same kind of anxie- 
ty as the Reichstag Building or the Jewish Museum in Berlin do when wrapped in textile.

The Idea is at the beginning and end of everything. We can reach the Idea both by summarising singular facts and dividing the Sum into the finest singular parts. In principle, there is no difference which end we start from: both ends move through the infinite and boundless Entirety, one as the shadow of the other, two unicellulars stuck together at the bottom of an ocean. It is just our fantasy that discussion of the first involves discussion of something that can be dissected on a lab table, and discussion of the other involves discussing something that isn't fully known by anyone, something existing besides the architecture theory discourse and revealing itself somewhere in the forecourt of a university or in the Supilinn area of Tartu, momentarily, at a time when Christmas night is giving birth to ever-new stars. According to Henri Lefebvre, it is not possible to grasp the second Idea by any category of abstract logic. ${ }^{5}$ Besides the past and future defined by discursive learning, there is another, serving the present from the lower levels of the subconscious, setting free a waiting, unassailable emotion, allowing the pearl diver to go on with his quest at the bottom of the ocean, at the place of waiting treasures not yet measured or weighed, waiting to be taken up to the sunlight.

Whatever our position on the concept of objective reality, the space of our own making extends a good deal further than the conventions coded by our culture that unify both possible extremities - the object as well as its content ${ }^{6}$ - still questioning what in fact the primary is, what is still real and what merely imaginary, how much faith we should have in the backside of the pale façade on the Emajõgi Athens that hides centuries of aesthetic history of lines and sights, which Clio has chosen as marks of memory, recognized as pillars of history in all their shape and fame. The world is constructed by us to have an "eminent" reality of ideas (Rene Descartes, Meditation VI). Space is what the cogito discourse prepares us to believe but not to trust, for it slips from our hands with every new touch. Space is like an essence that is caught in a net; it strips fish-

5 Henri Lefebvre, The Production of Space, trans. Donald Nicholson-Smith (Oxford: Blackwell Publishing, 1991), 4.

6 Ibid. 
ermen of their catch and leaves them drifting on the high seas, waiting for gales to capsize the lonesome boat.

As ordinary people, we do not recapture pillars or architraves but rainwater on the pavement and teary eyes. They both exist: the one we visualise through our cultural consciousness and the one that has been stored within the deep wells of our memory. In addition to social memory, a personal memory is revealed, storing personal and secret facts, those with no ties to a code or duty, and recollected as moments of joy or anxiety in the most unexpected place and unanticipated time. Recollections question us about our childhood, about some faraway continent, about the city that we have spent our lives in. In the other instance, the city does not reveal itself in the form of Ariadne's thread but as a representation of the Procrustean bed, stretching and cutting limbs: a revelatory vision within our dreams that emerges every time we open our eyes to see pillars and roofs, gates and backyards; the sight is dreadful and makes us doubt the midnight moonshine at the time when the last students return home. To recognise this particular occurrence of the city, we need the imagination liberated by thoughts and words to assign meaning and form to the metaphor that is born in the dark passages of the subconscious. We need a language to limn the city, one to substantiate a utopia and make Poliphilo's dreams once again alive and real.

New ideas have to fill the domain that does not exist in reality. A cultural shift concerning the conceptualisation of an artwork by the creative genius and by its recipient - the observer and the judge - is from end to end associated with Classical Philosophy and with the new Postmodern experience. A krater that has been emptied must be filled with new myths and utopias, thus returning shine and shape to the pearls that have been brought up from the depths of an ocean. Explication is just one way to appropriate objects and facts. We need light to perceive; to comprehend our vision we ought to have a round-table. Alongside the Aristotelian rule in science, it calls for others: philosophers, writers, artists and psychoanalysts. For the city where we live is much more abysmal and extensive than we imagine; there are black holes more unfathomable than our expressions in the language of science. 
THE IDEA AND THE ORDER

In the beginning there was the Idea, claims Plato. The first lines of the Old Testament read "the Spirit of God moved upon the face of the waters" (Gen. 1:2); in the endless and infinite void, in the unborn outer space apeiros (apeiros physis), time was measured in millions of years, seconds lasted for years and years were as long as years. Both Laozi and Nobert Wiener maintain that the void is the beginning and end of everything. The principles of the Classic era and the Germanic conception of space originate in the idea of the infinite continuity and expanse of the world, turning chaos into two-dimensional space and later into three-dimensional space, as we know with the help of geometry and the history of the arts. The Indo-European peoples' innate model of the world, regardless of their Greek or Semitic line of descent, is an ascetic empty container, holding a visual metaphor of a laundry line: facts are narrativized and then hung onto the temporal axis by the topos, whereas outside the cloister walls of the intellect there is a domain that Chronos has not touched: an unconquerable wilderness flowing like a river that man can never step into twice.

The universe was fashioned in agreement with nature's supreme laws (kata paradeigma tes diaiõnias physeos); the craftsman (dêmiourgus) gave these laws to the world as a gift, for us to recognise and utilise. In Timaeus, Plato relates the structure of the sky (Ouranos) to the sky itself. Earth becomes a visible mirror image of the invisible, an image that the cosmos has ordered with cosmetic powers, a place where the human wish to comprehend not only the function of singular parts, but also their meaning and reason of existence, has induced human beings to create new ideas and corresponding images of space that are an unmediated constituent and contingency of our existence. The Socratean belief in the prevalence of the Idea over matter gives it an upper hand in the construction of new cosmoses and worlds over and over again.

In Greece, the mythological conception of space-time is superseded by a conception of a particular area limned by space and time. The Latin word terrae designates both "ground" and "territory"; when subdivided into parcella, it becomes a component of city planning. Let no man enter the Academy who is ignorant of the spirit of geometry. For Plato, beauty was a truth that the Egyptians possessed in a "work of ten thousand years ago" as "rightful rules" (kala schemata). Space is an absolute, its 
visual metaphor a Vitruvian Man in the centre of a cosmic totality, designating both space and principles subordinated to it. The creation of an artwork that is part of a heavenly predestination - a cosmic order can never be better or worse than it is in the instant of that experience. ${ }^{7}$

"As Object opposed to Subject, as rex extensa opposed to, and present to, res cogitans, space came to dominate ... all senses and all bodies." ${ }^{8}$ Geometry and mathematics reign over history, history is ready in anticipation and merely waiting for someone to rip off its protective veil. The work of collaboration between Uranus and Gaia has disciplined the Occidental ego, enclosing science and the arts, sociology and literary studies. The right to rule and to instruct which has been given to mathematics justifies the determination and verification, alignment and hierarchisation of lives and subject domains - the domains that constrict the human primal freedom to bring into existence new spaces - so the reign of Order has suppressed our desire for the spontaneous and the experiential. The whole of action in space is actual. Yet our experience external to the limits of space is also outside the bounds of norm and form, assuming an inverted perception of reality and specifying the Idea as a transcendental substance outside our contact with nature, civilisation and ourselves.

Form is derived from the Soul, hence secondary already in its essence, whether it is the Form of nature or the Form of man, the things that he has created or the cities that he has built. "Orderliness can be attributed to things, a measure by which things are 'well' according to order or 'not' according to order." ${ }^{\prime 9}$ Order is the midwife of civilisation: it reduces the first to the second, offering our imagination a framework within its dream space: either the Greek polis or the ideal city of the Renaissance. The city of our dreams narrates a world that cannot and should not exist in reality. The apologetic disciples of Plato ought to chronicle the outside world introspectively; according to the customary definitions of the $16^{\text {th }}$ century theoreticians who followed Alberti, Filarete and Leonardo, one should assign the first place to the transcendental and the second to the immanent imagining. At the source of this utopia lies a deductive generalisation that carries over the laws of the microcosm to those

7 Nigel Spivey, Understanding Greek Sculpture: Ancient Meanings, Modern Readings (London: Thames \& Hudson, 1996), 26.

8 Lefebre, The Production of Space, 1.

9 McEwen, Socrates' Ancestor, 14. 
of the macrocosm; this deduction further entails an objective meaning within the subjective space that man has constructed, thus replacing a subjective cognitive experience with a cultural contract that enables us to see things in their new reality.

\section{ART AS STONE}

Continuing with the Classic era, we see that artistic vision is taken to be an instrumental part of imagination. Vision mediates the Idea. There is no man without art for, as Kantian thinkers have written, the world is materialised through imagination. Man actualises the world through his art; he becomes aware of the natural form and also gives nature a form, "For in every mind that once gives itself up to the purely objective contemplation of the world, a desire has been awakened, however concealed and unconscious, to comprehend the true nature of things, of life, and of existence."10 Lines and colours are the instruments of art: rules of arti del disegno and divina proportione are the devices to visualise the eyeless eternity. Contriving an image, they carry both natural and supernatural message as a mimetic hypostasis which we mistake for a copy of reality and quite often take for reality itself. Art is unique because it calls for a particular consciousness, allowing the area unbounded by rationality and cognition, by chaos and order, to bring into existence a new, "third reality", which has several defining qualities, in contrast to the ordinary consciousness: it establishes the criteria of truth for our "sensual journey" into the hidden wells of the subconscious. Criteria of truth are provided even when the artistic creation - which in semiotic terms can be treated as a text - does not constitute an open text but a closed circle, although it transforms potentiality and abstraction into the real, actualising the imagination of our mind in the form of a visual image through two approaches: either through the number magic and harmony of logic (consonantia), unity (integritas) and clarity (claritas), or through the mystical intuition. While the first approach retains an option to decode the text in accordance with the laws of analysis and synthesis, the second presupposes inexplicability: acceptance of the fact that conditions for being an artwork are not found in the openness but in

10 Arthur Schopenhauer, "On the Inner Nature of Art”, Philosophical Writings, ed. Wolfgang Schirmacher (New York: Continuum, 1994), 98. 
the closedness of the text. ${ }^{11}$ As an artistic metaphor, the death of Anna Karenina is as real as any other other proven narrative. ${ }^{12}$

The artist must create conditions for the birth of a new world so that figuration as an imagined imitation of objective reality can perish, its death offering an opportunity for a new visual truth that is similar to what we assume we see, although in no circumstances identical with it; it keeps bringing forth new imaginations and so provides an opportunity for the divine part of our self to escape and burst forth. "Now it must be seen that the stone thus brought under the artist's hand to the beauty of form is beautiful not as stone - for so the crude block would be as pleasant - but in virtue of the form or idea introduced by the art. This form is not in the material; it is in the designer before ever it enters the stone; and the artificer holds it not by his equipment of eyes and hands but by his participation in his art. The beauty, therefore, exists in a far higher state in the art; for it does not come over integrally into the work; that original beauty is not transferred; what comes over is a derivative and a minor: and even that shows itself upon the statue not integrally and with entire realization of intention but only in so far as it has subdued the resistance of the material."13 Aided by art, a new reality is formed - a reality not necessarily requiring a construction of three-dimensional space nor a perspective dependent on the human eye but, however extreme the case (e.g. Black Square by Malevich or Tatlin's Tower), the stone remains an unavoidable companion to the new reality.

Once again we must ask what art is and what role it plays in the construction of a city. Why should a city be beautiful in the first place, at a time when we could be content with its utility and an assurance that houses on its streets would remain firm? Why does a man decide to spend his leisure time willingly in Rome or Paris if he can afford to, in places where the dominance of monuments has so much complicated the air of nature? We ought to wonder what made Leon Battista Alberti, the first European architecture theoretician, write that beauty is a reasoned harmony so that nothing may be added or taken away, but for the worse. Beauty is an accord of all, a triumph on all bets, constructed to the numbered order and expressed through the rules of symmetry

11 Umberto Eco, Lector in Fabula (Milano: Bompiani, 1979), 14.

12 Eco, Assembly Hall Lecture at University of Tartu 6.5.2009, http://www.uttv.ee/naita?id=91 (accessed 2.9.2009).

13 Plotinus, Enneads, V. 8, 1.6. 


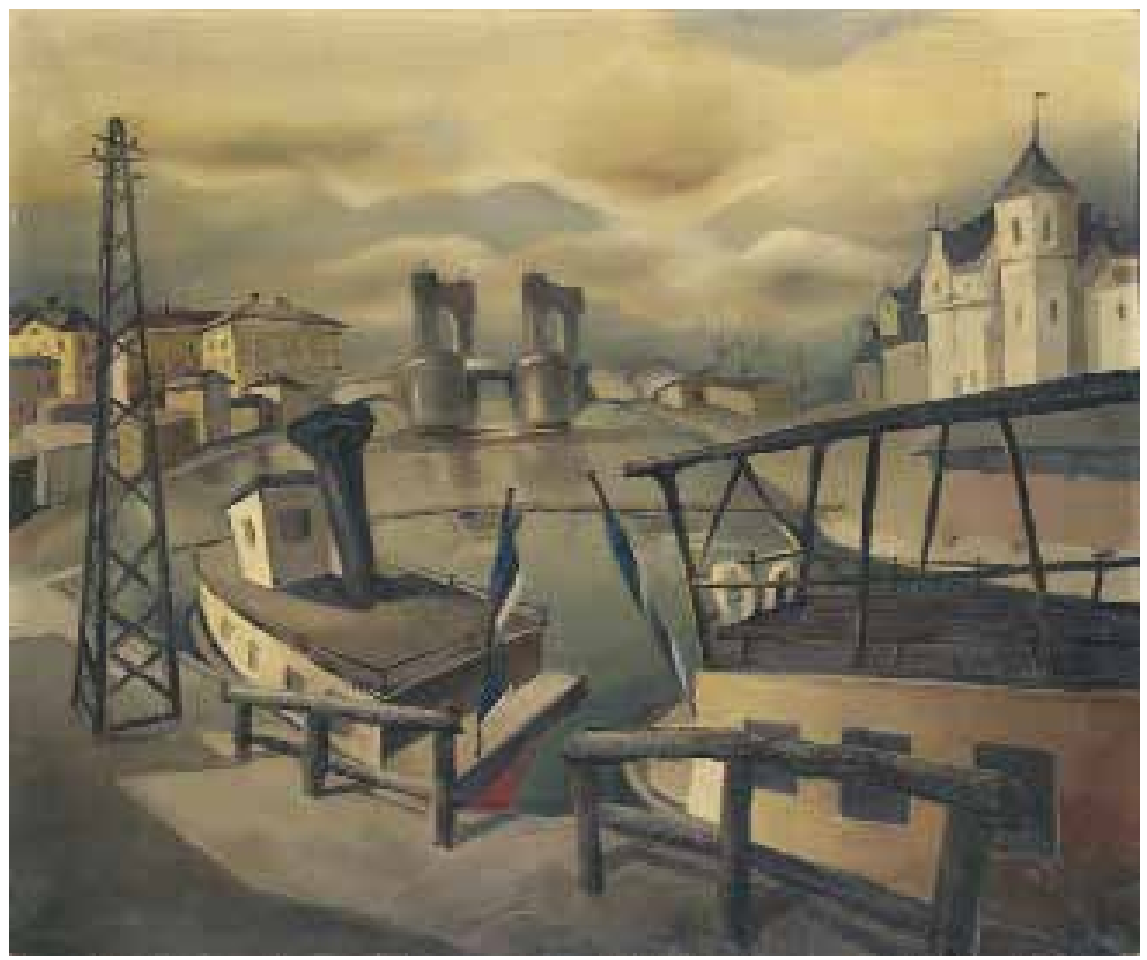

Fig. 2. Hando Mugasto, Tartu Stone Bridge, 1931, Tartu Art Museum

and Nature's demand for complete perfection. According to the rules of balance (concinnitas), a composition (callocatio) is formed from number (numerus) and the finite (finitio), enabling the expression of beauty (pulchritudo) as a harmony of all parts; such a harmony brings the world into agreement with the logic of the eye and mind. ${ }^{14}$

Art begins with an exploration of the visible world and leads to understanding. Following “Cennini's doctrine, art is the 'imitation', an action producing a replica." ${ }^{15}$ Alberti's art theory goes further in claiming that "we must always start with Nature and then choose its most beautiful aspects. For even Nature cannot anticipate all regularities of beauty and dictate their use."16 The new reality in art after Alberti is also known as

14 Leon Battista Alberti, De Re Aedificatoria, VI, 4. 5.

15 Moshe Barasch, Theories of Art 1: From Plato to Winckelmann (New York \& London: Routledge, 2008), 120.

16 Cecil Grayson, "Introduction", On Painting and On Sculpture: The Latin Texts of De Pictura and De Statua, ed. and trans. Cecil Grayson (London: Phaidon, 1972), 143. 
maniera moderna. It is distinguished from ordinary reality in that it does not imitate Nature but makes an ideal image of it. The Albertian paradigm is evident in the development of parks, architecture and painting. Hence, art intervenes decisively with the actuality lying before us as a panorama: now reality can be changed for the better in the mould of an imaginary space. The artist of the Mannerist era picks up every line and colour he recognises, subtracts and adds to them through his taste, fusing them into a whole that opens up as a horizon and his direction for the next explorations, "creating the relations between the early modern narrative and the fiction." ${ }^{\prime 17}$

Whereas Renaissance architecture generally expresses a charming play with space, the following era deformed Nature with a spontaneous fantasy. Borromini and Bernini initiated a movement in space that overruns, conquers and models; it gives the cosmos a shape that dislocates the ideas of a Copernicus within a convoluted sophistic system of a Tycho Brahe, disclosing a starry path of monads in the cosmos. The Beautiful is no longer merely a harmony but also an absence; beside the Classic reappears the savage. Observing the nature on the Gorgades Islands in the Aethiopian Sea, Bellori wrote: "where the three Gorgons, daughters of the sea-god Phorcys; the most beautiful of them, Medusa, arrogantly dared consider herself superior to Pallas for her form and the splendor of her locks, for which the angry goddess changed her blond hair into horrible and corrupted snakes and corrupted her face in such fashion that those who looked upon it were turned into stone."18

\section{CLASSICS AND THE SUBLIME}

Two kinds of Beauty exist: Apollonian and Dionysian. Both descend from the same family and have the likeness of children to the same father, yet they are separated by their natural talents. Close together, they dwell on Mount Olympus, passing to the arts a divine aura that, as Johann Joachim Winckelmann has noted, far surpasses our mortal capacity to interact with reality, providing an ideal position to evaluate art. "Just as

17 Susan Bruce, "Introduction", Three Early Modern Utopias: Utopia, New Atlantis, The Isle of Pines (Oxford: Oxford University Press, 1999), xi.

18 Gian Pietro Bellori, "Life of Annibale Carracci", The Lives of Modern Painters, Sculptors and Architects. A New Translation and Critical Edition, ed. and trans. Alice Sedwick, Helmut Wohl, Tomaso Montanari (Cambridge: Cambridge University Press, 2005), 81. 
Homer's description surpasses the attempt by all other poets," ${ }^{\prime 19}$ Classic beauty offers a path to perfection but also establishes a norm that makes a subjective judgement of taste an objective measure. This norm exists as a method in the history of art both inside and outside historicism: it belongs to the historical process and carries the aims of its times. ${ }^{20}$ Our standard for city planning is shaped by the Virtuvian venustas - a subjective standard in itself - but in the prescriptive hindsight of the historical truth the category becomes clear and can be clearly characterised.

The art theory of the Enlightenment is held captive by the dictate of the Classics: it has a stake in the apparent unity of content and form, yet it shrouds the dualities of our nature, leaving differences out of sight. However, Marsilio Ficino's writings convey more a concern about the freedom of choice than an interest in the gout grec, a topic which the literature of architecture and aesthetics from Charles Perrault to Alexander Baumgarten made known as a method, distinguishing bright and dark features of a work, its aistheta and noeta (artistic and common aspects). The first pertains to the domain of aesthetic thought, while the second pertains to the logics. ${ }^{21}$ This risk - being trapped between a thought and an emotion - has been one of the main issues in the history of art and aesthetics since the Enlightenment. ${ }^{22}$ ("Poetry comes before the intellect, but after Feeling... [P]oetry being composed of passion and of feeling, the nearer it approaches to the particular, the more true it is, while exactly the reverse is true of philosophy."23)

The object-subject relations dilemma of philosophy is additionally cast as a judgement on the artistic reality of nature and culture, free beauty (pulchritudo vaga) and dependent beauty (pulchritudo adhaerens), giving the pattern of pillars in front of the university both emotional and rational significance. Aesthetic experience precedes abstract generalisation; its actual content is difficult to describe outside the artistic encounter.

19 Johann Joachim Winckelmann on Apollo Belvedere, cit. in Hugh Honour, Neo-Classicism (Middlesex, England: Penguin Books, 1968), 60.

20 Donald Preziosi, "Art History: Making the Visible Legible", The Art of Art History: A Critical Anthology (Oxford: Oxford University Press, 1998), 25.

21 Alexander Baumgarten, Mediationes, philosophicae de nonnullis ad poema pertinentibus [1735], $\$ 10$, cit. in Jyri Vuorinen, Estetiikan Klassikoita (Helsinki: Suamalaisen Kirjallisuuden Seura, 1996), 139. 22 Christian Norberg-Schulz, "The Age of Baroque and Rococo", The Triumph of the Baroque: Architecture in Europe 1600-1750, ed. Henry Millon (London: Thames and Hudson, 1999), 113.

23 Benedetto Croce, Aesthetics as the Science of Expression and General Linguistics, trans. Douglas Ainslie, The Project Gutenberg EBook \#9306 (2005), http://www.gutenberg.org/ebooks/9306 (accessed 14.10.2013), 90. 
Therefore, the dividing line between object and subject is tentative and reflects reality - whatever it is - only conditionally. Denis Diderot stated this idea in his foreword to the Encyclopaedia, or a Systematic Dictionary of the Sciences, Arts, and Crafts: "even when a work of art reveals itself to the viewer as descriptive or realistic, it in fact borrows the matter from our own eyes, foregrounding the outcome of creative activity and the bursting impulse leading to it; artwork brings forth the essence of things thus the identity of substance, it describes the subject or object through a participative act, forming the surrounding natural universe by means of a network of symbols that as signifying representations relate to the meaningful perceptions of human beings." 24

The beautiful is agreeable; it helps imagination (Einbildungskraft) to find a place at the level of understanding (Verstand). ${ }^{25}$ "Objects are given to us through our sensibility. Sensibility alone supplies us with intuitions (Anschauungen). These intuitions become through the understanding (Verstand), and hence arise conceptions (Begriffe). All thought therefore must, directly or indirectly, return to the intuitions (Anschauungen) i.e. to our sensibility, because in no other way can objects be given to us," wrote Immanuel Kant. ${ }^{26}$ So the gates open for an understanding of objects not solely as objects, nor as results of a pure intellectual effort, but contingent upon several often contradictory processes, relating cogito to facts and facts to our deeper ontological memory with an a priori living image of space, a city, its streets, backyards and roofs. So the state of rest becomes a process, approximating the trajectory of our movement through time and space and depending on the seasons, as well as on the instant imposed by the placement of clock hands. It is then we meet the city, the person and nature in the everyday and in the sublime, an artwork of colour blobs reflecting on the retina.

"Thus reason becomes involved in darkness and contradictions ..." ${ }^{27}$ Impressions appear like black holes in the cosmos, outside of measurable time and space, recognised in the depths of the unconscious; impressions take shape, generalise the particular, extend the limits and our share in realism; they give voice to an echo and through a mental

24 Denis Diderot, Diderots Enzyklopedie. Die Bildtafeln 1762-1777 (Munich: Südwest Verlag, 1979), xiii.

25 Immanuel Kant, Kritik der Urteilskraft (1790), vi, xxxix.

26 Kant, Critique of Pure Reason (1781, 1787), The Transcendental Doctrine of Elements, B33, trans.

F. Max Müller, ed. Allen Wood (New York: Modern Library, 2001), 42.

27 Kant, "Preface to the First Edition", Critique of Pure Reason (1781), aviii. 
action turn a musical score into a symphony. Abstraction is flawlessness, an unreachable goal, a perfected particular and therefore its own absolute that within its incompleteness expresses our inexhaustible essence. In abstraction, we are always - no matter where and when - met with chaos. It accompanies man from birth to death and is, in Kant's account, grander than anything we can ever find in nature. ${ }^{28}$ The sublime was considered an antipode of order as early as in Horace's poetry. For him, the sublime signified a sorrow born out of silence, a feature of a particular state of mind: a transcendental expectation of the supernatural. "Derived from the Latin sublimis, a combination of $s u b$ (up to) and limen (lintel, literally the top piece of the door) ... the word has many applications ... Peri hypsous or On Sublimity ... sometimes attributed to Dionysius Longinus, it was originally derived from the political rhetoric (from the texts by Cicero), as a combination of inventio (the gathering of relevant subject matter), dispositio (the process of composition), elocutio (the theoretical base), memoria and actio (punctuation of the speech). On the other hand sublimity was interpreted as the emotional category, which 'pulverizes everything up like a whirlwind' or 'pulverizes all the facts like a thunderbolt'."'29

The sublime is greater than life and more potent than art. Its touch terrifies, enclosing an eternity within an instant and making the instant last for an endless eternity. Through the sublime, the concepts of time and space are ascribed new meanings. The rebirth of the sublime in the European cultural consciousness is associated with John Milton, Joseph Addison and, most of all, with Edmund Burke, whose interpretations employ a Neo-Platonic idea of the constant and unchanging condition of the Soul to describe the cognitively impenetrable and altered spiritual condition, presenting us with the world not only as a framing and a perspective, but also as the content which enables us to touch the depths, not to mention the real source, of art. "The passion caused by the great and sublime in nature, when those causes operate most powerfully, is astonishment, is that state of the soul, in which all its motions are suspended, with some degree of horror. In this case the mind is so entirely filled with its object, that it cannot entertain any other, nor by consequence reason on that object which employs it. Hence arises the great

28 Kant, Critique of Pure Reason, 32.

29 Philip Shaw, The Sublime (London, New York: Routledge, 2006), 12. 
power of sublime, that far from being produced by them, it anticipates our reasonings, and hurries us on by an irresistible force. Astonishment, as I have said, is the effect of the sublime in its highest degree, the interior effects are admiration, reverence, and respect," wrote Edmund Burke in $1753 .{ }^{30}$

\section{CITY AS A CATHEDRAL AND CITY AS A TEMPLE}

One part of the city is shaped by the Classics and becomes an endeavour we cannot accomplish in its ideal form. The other part is a deviation that exists in our nature as free will; it breaks through dams and obstacles, it rises and falls, and it finds a new bed as does melted snow, rushing down the mountainside in the spring. The metaphor to represent the first is a temple, and the second a cathedral. In European thought, together they signify the Pillars of Hercules that allow ships to pass onto the high sea. Architects and galley slaves, a workforce whose palms are blistered, are thus prepared to convert the past into the future in the name of a dream. Tartu is built on the marsh of the River Emajõgi, the foundation of its buildings is in the water, and quite a few of them are crooked, especially if we pass the city centre, off the town square and away from the main building of the university, towards the outskirts. Beyond the straight line that testifies to the human wish to conquer nature, we encounter a bend, ill-defined and unclear; it is a freedom (libertas) which we never completely understand and therefore - thank god! - are not able to absorb with our noetic instrumentation, a bend that in our polarised dualistic conception of the world is conventionally compared with the Cartesian notions clarté et distincté. The bend awaits anyone who reaches out for light from the bottom of a valley, hidden in a place where an animal lies in wait and no man can go his way. ${ }^{31}$ Are straight lines and bends qualities of matter or mind? Is the imagination that delivers our emotional states, such as happiness, peacefulness, disappointment and anger, caused by external factors that are qualities of matter and its form (architectural work, for example) and so give us a

30 Edmund Burke, A Philosophical Enquiry into the Origin of Our Ideas of the Sublime and Beautiful With an Introductory Discourse Concerning Taste; And Several Other Additions, A New Edition MDCCXCVIII (London, 1798).

31 With reference to Dante's Divine Comedy, Haljand Udam, Orienditeekond (Tartu: Ilmamaa, 2001), 116. 
basis for an aesthetic appreciation? Or are these qualities the subject's pure expression of cultural belief - both collective and individual so that once sown in the ground of civilisation, they freely burgeon, bloom and wither? What is the significance and semantic content of the Latin notion genius loci, "spirit of a place", cited by poets from Horace to Alexander Pope and stretching from the discussion of the sublime to contemporary city planning theory? "When God said to Adam: You shall be a fugitive and wanderer on the Earth, he put man in front of his most basic problem: to cross the threshold and regain the place", noted Christian Norberg-Schultz ${ }^{32}$, establishing a new way of thinking about the city as an interlocutor between nature and man.

The city as a cultural paradigm asks the question: to what degree are those who built Tartu - Johann Wilhelm Krause, Karl Morgenstern, and Georg Friedrich Parrot - and those who retrospectively appreciate and read their work, bent under the inescapable rule of objective reality? What is art history, and where is it situated in the mental and physical landscapes of our intellect? What brings about the pleasure of recognition and cathartic emotion, stopping us in a museum in front of some paintings, while leaving us untouched by others? Where are the secrets buried that contain the key to the source of art and what is really expressed through the lived experience of being at the ruins of the Tartu Dome Church or standing in the city centre in front of the main building of the University? To what extent is this a case of hypothetical necessity, i.e. the efficient cause of all action and passion, the motionless touch that in indefinite and all-compassing eternity gives birth both to chaos and the cosmos, a place where just one motion is natural, namely that it "cannot be stopped moving in this way"?

Whether beauty is an object or a subject is hardly a question that can be appropriately addressed within the scope of this article. The battle of giants between Materialism and Idealism is far from over; it endures as a Holy War between two world-views and two beliefs. When objectified, beauty becomes a principle that by the lights of art historians and city planners is a nomen; it is the substance of building material and shows a tendency in Western culture to lean towards the static and the lasting, and away from the dynamic and the changing. This observa-

32 Norberg-Schulz, Genius Loci, 23.

33 David Rostock, "Introduction" to Aristotle, Physics, trans. Robin Warerfield (Oxford: Oxford University Press, 2008), lxiv. 
tion enabled Martin Heidegger to claim that "a building, a Greek temple, portrays nothing. It simply stands there in the middle of the rock-cleft valley. The building encloses the figure of the god, and in this concealment lets it stand out into the holy precinct through the open portico." 34 At the same time, being an object is its function in existence as a building; a building transforms the world around us into a monument, into something we evaluate and remember, formulating a visual vocabulary, a Vitruvian way of building temples, bridges and cities. For art, however, this is just a single specified method to proceed. In Heidegger's words, "this resting of the work draws up out of the rock the mystery of that rock's clumsy yet spontaneous support ... It is the temple-work that first fits together and at the same time gathers around itself the unity of those paths and relations in which birth and death, disaster and blessing, victory and disgrace, endurance and decline acquire the shape of destiny for the human being." ${ }^{35}$

Apart from being constructed according to simple and true mathematical rules, the temple is in every aspect united with the human being and his body, for the inevitable bodily imperfections announce the closeness of the deity. When our reference point, our point of contact and our emotions change, the temple is born anew, opening up various other choices beyond linear time and three-dimensional space. Yet there is a quasi-logical presupposition of an identity between "mental space" and "real space" in the interpretation and understanding. ${ }^{36}$ By celebrating the temple, man celebrates the eternal in its material form. To think otherwise and to think of another suggests a deviation from the path that Vitruvius once established; it suggests wandering in the marshes of the River Emajõgi, between the foundations that are built on soft ground, between bent horizontals and angles. While a Supilinn fencepost or a housetop might crumble on a wet morning, ideas about the city still stand.

The other and equally important level of our consciousness is shaped by the unstoppable flow of time, which brings the ever-changing and the singular into view: time selects persistent ideas from the continu-

34 Martin Heidegger, "The Origin of the Work of Art", Art and Its Significance: An Anthology of Aesthetic Theory, trans. Albert Hofstadter, ed. Stephen David Ross (New York: State University of New York Press, 1984), 263.

35 Ibid.

36 Lefebvre, The Production of Space, 6. 
ously renewing moment, here and now. "The Postmodern sublime ... is defined not by its intimations of transcendence but rather by its confirmation of immanence." ${ }^{\prime 37}$ The Kantian subject-centred world-view is given a new opportunity to interpret the external facts and the internal, the primary and secondary qualities. Paul Ricoeur has addressed the question of time and memory. He distinguishes between the reproduction of past facts and the creative acts of transmission. ${ }^{38}$ It is through this distinction that a mimesis-like repetition reveals itself as a mneme, is given wings of fantasy, and noesis comes to mean noema or, in the words of Husserl: "corresponding to all points to the manifold data of the real (reelle) noetic content, there is a variety of data displayable in really pure (wirklicher reiner) intuition, and in a correlative 'noematic content', or briefly 'noema' - terms which we shall henceforth be continually using." ${ }^{\prime 39}$

At birth, the human being is endowed with the premise of understanding the qualities of space and time; yet someone has to help him, organising autumn schools etc. A particular technique must be proposed, enabling the shift from copying, evident in the most primitive of creatures, to an active use of memory in the creative process, thus putting man into the footsteps of the supreme being. Only the second phase of memory, the one that our fantasy (phantasma) relies on, permits the primitive imitation to grow into an active production of forms; so every time we experience Rome, "one that once has been built in tuff and travertine" has turned into marble and then crumpled. Fate is unpredictable. The question of why ruins are better understood by the elderly mind than by nations that were only recently invited to the culture hub is easy to answer: for a young person, time marches inexorably on, in one direction (what else could a child know before growing up). Whereas an aged man, having endured a life and maybe even two, is prepared to believe that time is reversible, that past can grow into future. Henri Bergson writes about this: space can simultaneously be a prison and an outpost of freedom.

37 Shaw, The Sublime, 3.

38 Paul Ricoeur, Memory, History, Forgetting, trans. Kathleen Blamey, David Pellauer (Chicago: The University of Chicago Pres, 2004), $6 \mathrm{ff}$.

39 Edmund Husserl, Ideas: General Introduction to Pure Phenomenology (also known as Ideas I), trans. W. R. Boyce Gibson (New York: Collier Books, 1962), 238. 


\section{THE ANOTHER TOWARDS THE DIFFERENCE}

You, reader, believed that there, on the platform, my gaze was glued to the hands of the round clock of an old station, hands pierced like halberds, in the vain attempt to turn them back, to move backward over the cemetery of spent hours, lying lifeless in their circular pantheon. But who can say that the clock's numbers aren't peeping from rectangular windows, where I see every minute fall on me with a click like the blade of a guillotine? However, the result would not change much: even advancing in a polished, sliding world, my hand contracted on the light rudder of the wheeled suitcase would still express an inner refusal, as if that carefree luggage represented for me an unwelcome and exhausting burden. Something must have gone wrong for me: some misinformation, a delay, a missed connection...

Italo Calvino, Se una notte d'inverno un viaggiatore ${ }^{40}$

We are needed but as conductors interposed between two separated categories: the past and the future. ${ }^{41}$ We represent an immovable point that from within continuously pushes forth the lived experience, bestowing the primary cause with new dependencies; some things will be left out and some things will be chosen, converting memory (moneo) into monument and art into stone. Our cities are similar to cemeteries. Walking among these graves, we are equidistant from the past and the future, yet we long for both, just as we long for a life lost or a lost love because, unlike life, which changes and transforms, death lacks one important attribute: possible contact with the moving and the changing. So a ticket to board a train is a chance to find one's place and participate in the world of continuous movement and becoming. The topic I would like to conclude with is motivated by the present, its sweeping extension, which exists as the only actual reality until we close our eyes and the temporal gives way to the eternal. The journey to the domain of Hades not only signifies a farewell to the human-imposed space but also a parting from the limits of time.

What man cannot reach within his time, he attempts to create in the surrounding space. The builders of temples and cathedrals have always

40 Italo Calvino, If on a Winter's Night a Traveler, trans. William Weaver (San Diego: Harvest Book, 1981), 11.

41 Henri Bergson, Matter and Memory, trans. Nancy Margaret Paul, W. Scott Palmer (London: George Allen \& Unwin Ltd, New York: The MacMillan Company, 1929), 88, 93 et al. 
been ambitious to break the enchanted circle of life and death, to find less frail, grander artefacts to preserve their names. The university building with its six pillars is a sign, a vivid proof of this aspiration, enabling us to feel the potency of an idea and its embodiment, its frozen stone walls and columns expressing the abstract through the particular of the pictorial imago. Turning the internal into the external, architecture is always there to be rediscovered, the imagination of its maker once again cast into the eyes of the beholder. Imagination is not the capacity to merely reproduce nature but to re-figure it, to meet chance through the experience of art; it is not a fixture: instead of the "structuralist invasion" both in terms of history and space, it is the "'hidden art' that cannot be revealed to the eyes." One has to be separated from oneself in order to "be reunited with the blind origin of the work in its darkness ... For Kant, imagination was already in itself an 'art' ... which originally did not distinguish between truth and beauty." ${ }^{\prime \prime 2}$

The core ideas of European epistemological art theory since Augustine of Hippo have not been greatly influenced by the daily tides, nor by the questions of the current environment or politics. Up to the present, we believe that beyond the actual world there is another, one that exists as a stone in its metaphysical objectivity, the stone carrying within the invisible outline of a shape so that the third eye of a "genius" can recognise $\mathrm{it}^{43}$ on the way from Supilinn to morning mass on a Christmas day. The City, myself, time and space, these words we say in one breath; all these words describe the city, the panoramic view around us, as a boundless semiosis: one semiosphere cutting into another and clinging to the dirty boots of a peasant, like in the Cézanne painting that was made famous by Merleau-Ponty. While the space of the main building of the university exhibits the soberness of a Classic, susceptible to breaking in the cold like an ice crystal, the surrounding city is reminiscent of a waxwork campanile or a mother's arms; it is so much softer and, contrary to fatherly love, it can give birth to new pairs of eyes. ${ }^{44}$

The city reveals itself to us not within the domain of rationality or the allodium of sensatio, but as a sovereign entity, situated on the demarca-

42 Jacques Derrida, "Force and Signification", Writing and Difference, trans. Alan Bass (London: Routledge, 1978), $6 \mathrm{ff}$.

43 Juhan Maiste, Kolmas silm. Essee ilusast maastikust (Tallinn: Varrak, 2002).

44 Maiste, "Supilinna romanss. Valge võim ja mustad noodid", Acta Architecturica Naturalis, 2, Supilinn (Tallinn: Tallinna Tehnikaülikool, 2012), 25. 


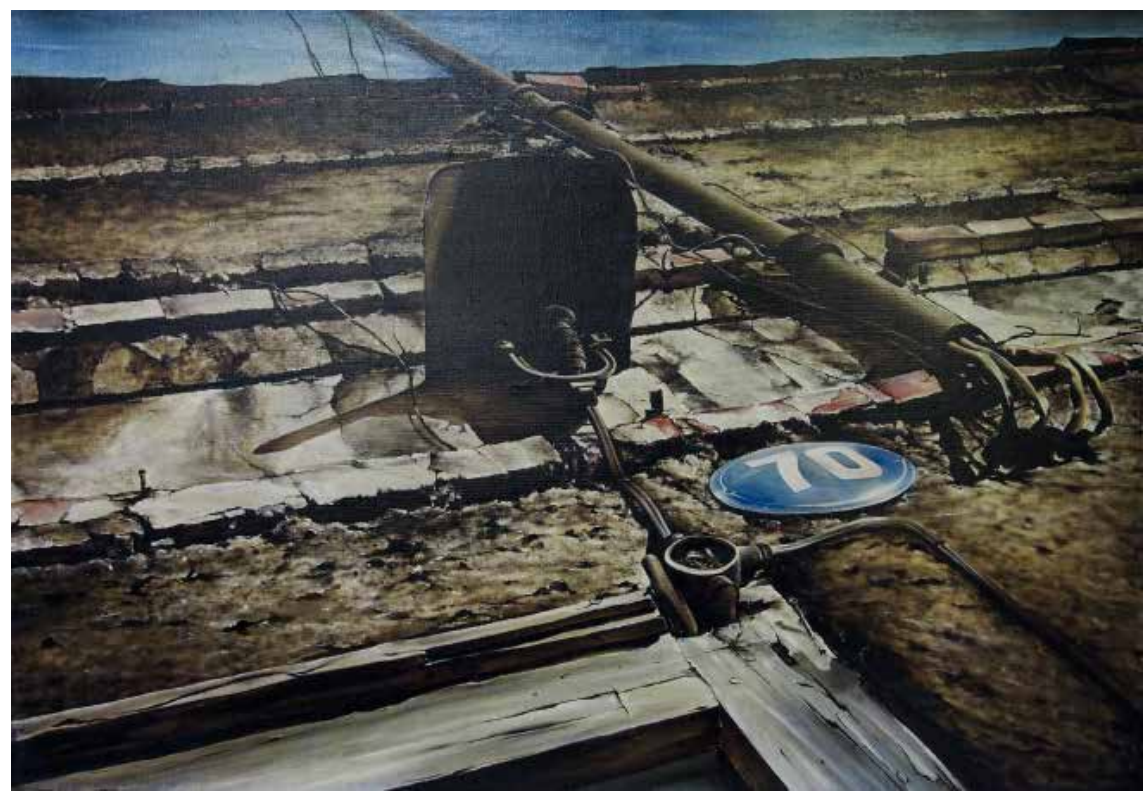

Fig. 3. Viljar Valdi (Ilmar Kruusamäe), Unelectrified Landscape, 1984, Tartu Art Museum

tion line between the object and subject, ruled by chaos and order; its midwife is chance and its documented place of birth is the present moment. Those who build the city are not given a title of nobility; instead, issues of obligation arise: who gets the last laugh? For Deleuze, "exhaustion and fatigue are necessary aspects of the first synthesis of time as passing present ... The symbolic image enables processes of assembly, ordering and sensation." The present is the first synthesis of time, a "passing present" constituted of many durations or stretches that overlap. ${ }^{45}$ The first and the second city both inhabit us: a whole is formed when brightness and darkness, the earth and the heavens, the spiritual and the corporeal speak in unison, aiming for harmony - when the earthly and the heavenly are in accord, one can hear the miraculous sounds of the lyre. If the lyre were broken into pieces, fractured, its strings ripped, a harmony would still remain. ${ }^{46}$

We still miss the unmediated touch of the city and this absence can never be repaired. "It is as impossible to wake the dead as it is to re-

45 James Williams, Gilles Deleuze's Philosophy of Time. A Critical Introduction and Guide (Edinburgh: Edinburgh University Press, 2011), $11 \mathrm{ff}$.

46 Plato, Phaidon, 86. 
pair anything that has ever been great or beautiful in the architecture ... The first step to restoration (I have seen it again and again, seen it on the Baptistery of Pisa, seen it on the Casa d'Ora at Venice, seen it on the Cathedral of Lisieux), is to dash the old work to pieces; the second is usually to put up the cheapest and basest imitation, which can escape detection. ${ }^{\prime \prime 7}$ Which city we live in - the static or the dynamic, alien or our own - is a question of choice. Which of them should we trust: the idea that existed before the matter or the idea that we derive from it. This question was described by Aristotle and, in his stead, within the analytic method. Under the aegis of science, it has objectified an utopia: a wish to explain everything that is intermediated to us by our senses. What we cannot see, we hope will appear on the blue screens of scientific explanation tomorrow. Our psychological self is part of the external reality: the reality that a bystander can study.

Surveying the city with the help of the scientific method, we get an overview of its population and dynamics, its squares, parks and boulevards, a friendly voice of a navigation system leading us safely to our destination. Even if we do not wish to arrive. Coincidentally, our free will is surrendered, and content becomes a container and determines the state of city planning through socialisation and rule of law. Regulations lead our line of reasoning back to the beginning, requesting answers with the force that Merleau-Ponty describes: "Kant tried to draw a strict demarcation line between space as the form of external experience and the things within that experience ... there is naturally no question of a relationship of container to content, since this relationship exists only between objects, nor even a relationship of logical inclusion, like the one existing between the individual and the class, since space is anterior to its alleged parts, which are always carved out of it. Space is not the setting (real or logical) in which things are arranged, but the means whereby the position of things becomes possible." ${ }^{\prime \prime 8}$

All in all, is it possible to know anything about the external, things that we do not intuit or find written onto the future map of the memory? Does the city exist beyond our line of sight, does the unreadable and the unspeakable exist at all? We cannot approach the city without first finding an answer to the question of the surrounding void and space. Sailing

47 John Ruskin, The Seven Lamps of Architecture (New York: Dover Publications, 1989), 194-195. 48 Maurice Merleau-Ponty, Phenomenology of Perception, trans. Colin Smith (London \& New York: Routledge, 2007), 283. 
westward towards India on the Santa Maria, we discover America. It is a land where maize and potatoes grow, where the Incas have played ritual ball games throughout time. Something is continuously happening there, something that we are aware of, and so it can answer questions before they are asked. The world reveals itself to us in the manner that we are prepared to explore it. The city consists of views and perspectives, prepared for us by the hand of the Great Architect. "Through the action of culture, I take up my dwelling in space - in lives that are not mine." ${ }^{\prime \prime 9}$ Which of these stories and stances truly belong to me: the one I recognised at dawn in the silence of Supilinn, or the other - a shadow I tried to avoid meeting. How can we be certain in the unseen, in things we are not able to perceive because they are obscured, things we have not yet learnt and others which might appear in the form of another?

\section{DERRIDA AND THE CITY}

One of the prominent contemporary theories of city planning is found in Italo Calvino's study Le città invisibili, which against the odds exemplifies a departure from the "modernist thought" that characterises much of the $20^{\text {th }}$ century. Calvino's theory has matured in the shadow of PostStructuralism, emphasizing the subjective and experimental aspects in its definition of the city. The development of the theory is premised upon two disciplines that rely on the philosophy of language: phenomenology and linguistics, the latter being the source of theory's novelty: seeing unity in object-subject relations in place of the earlier separation; the approach was based upon analytic philosophy, until influenced by the hermeneutics from Frege to Ernst Cassirer and Hans Georg Gadamer. Even then its positions differ from the analytic tradition in several ways. "Where one is forced to take the meaning of words as mental images or acts of an individual mind, and thereby to change the idea of constant to continuity, described by Jacques Derrida as desire to produce the dynamics of contradictionary coherence, when the philosophy seeks to ground the explanatory claims of its items of presence." ${ }^{50}$

49 Merleau-Ponty, Indirect Language and the Voices of Silence. The Merleau-Ponty Aesthetic Reader, trans. and ed. Michael B. Smith (Evanston, Illinois: Northwestern University Press, 1993), 113.

50 Paul M. Livingstone, Philosophy and the Vision of Language (New York \& London: Routledge, 2010), 27. 
Everything that happens takes place in the present moment. To understand this, an understanding of the city in all its physical, spiritual, sensual and intellectual, pictorial and significatory pluralism is needed. Only the city of our lived experience is real: the one we love and hate, and meet again and again. To discuss the city it does not suffice to decompose it: an analytic operation, although it can fix the perceptible, rarely leaves space for the invisible, the other that Yuri Lotman diffidently has coined the semiosphere..$^{51}$ The city, however, is to the semiosphere what a symphony is to a solo violin; its notes hang underneath the cupola even at the instant when the fugue stops. The theories of city planning are still dominated by structuralist and iconological approaches, still addressing the city that is squeezed between the covers of Ten Books on Architecture. This is, however, just half of the truth. As such it is not only incomplete, it is also dangerous, for our discussion of white leaves out the black. The imaginary antipode of chaos is order, but the city demands chaos, and it requires dark streets and a Bermuda Triangle where people and ships, filled with the ballast of dreams, may disappear before the dawn, red canvas on sails.

The spirit of Aleksander Müller lurks in a dimly lit corner there and, before the sunrise, the bar Zavood coughs out of its throat those who envision cities that Calvino named after goddesses: Diomina, Isidora, Anastasia, Tamara, Euphemia, Lendra etc. But then, strolling in Supilinn, on the streets sculpted by the dark soil and rain, we begin to miss the marble of the University City. Poetry is born where the chaotic and the orderly meet, in a moment that is unfixed on the temporal axis between the past and the present. This place is named after its French inventor: it is Différance, the notion of such a small difference that Derrida tells us cannot be heard, for it is not a voice, not a writing either: it is situated in the space and void between the two. ${ }^{52}$

Différance is not a language, nor is it situated outside of it; for Derrida, nothing exists beyond language: "there is nothing outside the text." Everything that takes place is somehow heralded, and becomes known through the capacity of the forma to produce mental imagery from words, pictures, sounds and tastes; unlike analytic operations, which for Descartes were associated with the creative activity of the brain, the

51 Yuri M. Lotman, "On the Semiosphere”, trans. Wilma Clark, Sign Systems Studies, 33.1 (2005).

52 Eva-Maria Maiste, Differance' i avanemisest teises Jacques Derrida filosoofias, master's thesis (Tartu Ülikool, 2013). 
whole of the body is involved: the senses, heart and vessels; the forma hence announces its presence through the cathartic instant, touching us from the inside and then from the outside, announcing itself both as a happy movement of the diaphragm and as a recognition and a pleasant memory, one that we label with a notion borrowed from agriculture: "culture". Art is both the popping crop and the corn on the crossbar of a barn; it is the ideational motion towards the supreme and a particular reference to a source. Art not only turns the world into colours; all told, art calls the world into existence.

The question of being is as worthy a subject as the essence of art: neither is famously a suitable subject matter for the gentlefolk; yet it is because of its unconventional nature that this question is fit to conclude our discussion, which borders the conventional and the unconventional, the University City and the alma mater. "Under the apparent diversity of the historical forms of art, the concepts of art or the words which seem to translate 'art' in Greek, Latin, the Germanic languages, etc, one would be seeing a one - and naked meaning (un sens $n u$ ) which would inform from the inside, like a content, while distinguishing itself from the forms which it informs." ${ }^{153}$ Anything can be studied, whether matter or ideas, but we must remind ourselves that no man can reach beyond the knowable. If it ever were to be, it would happen in the frail light of a sunrise while splashing our eyes with the crystal-clear water from a well filled from the Castalian spring.

53 Derrida, The Truth in Painting, trans. Geoff Bennington, Ian McLeod (Chicago \& London: The University of Chicago Press, 1987), 22. 
Juhan Maiste: This City And Another

KEYWORDS: ORDER, CHAOS, ART, ANOTHER, DIFFÉRANCE

SUMmARY:

The article examines the notion of city in its two expressions. In the first, reader is introduced to the analytic method and its Vitruvian source. In the second, several possibilities of phenomenological approaches are weighed and the Cartesian cogito discourse together with its cognitive framework is re-conceptualized and a new approach is posited. In the Classical conception of time, its beginning was an indivisible entirety (apeiros) that Chaos separated from, then with the help of gods, moon, stars, and planets were born from the Chaos. The precondition for the Renaissance school of perspective and for plans of the ideal city, is order and geometry that helps man to create his own world, to give an idea a form and signify man-made things. The author attempts to extend the genius loci, a notion previously employed by Christian Norberg-Schultz, based on preceding work in the tradition of classical phenomenology from Immanuel Kant and Martin Heidegger onward, the semiotic aspect of perception found in Yuri Lotman's work is integrated with the phenomenological thought of Maurice Merleau-Ponty and Paul Ricoeur. Also, Jacques Derrida has a prominent place in the text, the author owes him the primary example - treatment of the University City in its visible and hidden extensions. Together these extensions express the difference between two poles of knowledge - united in the notion différance.

\section{CV:}

Juhan Maiste is professor and Head of Department of Art History at the University of Tartu. As a prolific writer he has authored a large number of of monographs and articles on architecture, classicism, cultural heritage, the philosophy and poetics of art history. Also among his scholarly interests have been Estonian and Livonian manor architecture, the phenomenon of park landscapes as well as the work of Johann Wilhelm Krause. In addition to teaching and research, professor Maiste curates the publication of the Baltic Journal of Art History. 